7. Reprod. Fert. (1966) 12, 373-375

BRIEF COMMUNICATION

\title{
THE EFFECT OF PLASTIC DEVICES IN THE UTERINE LUMEN ON PREGNANCY AND PARTURITION IN THE RABBIT
}

\author{
EVA BROWN AND R. H. FOOTE \\ Department of Animal Science, Cornell University, Ithaca, Nere York, U.S.A.
}

(Received 11th February 1966)

Recently there has been considerable interest in the use of intra-uterine contraceptive devices, but their mode of action is unknown. Much of the successful interference with pregnancy in laboratory animals has involved the placement of sutures into the uterine wall (Doyle \& Margolis, 1963, 1964; Eckstein \& Adams, 1964; Marston \& Chang, 1964; Zipper, Garcia \& Pastene, 1964; Adams \& Eckstein, 1965a, b; Kar \& Kamboj, 1965). In the present experiments the plastic devices were simply inserted into the lumen of the uterus, so as to allow some freedom of movement. This parallels their use in humans, and avoids possible complications in interpreting results where sutures penetrate the uterine wall. The experiments were designed to determine both implantation and kindling rates and to note the effect of the devices on the corpora lutea, since foreign bodies have been shown, in the cow, to interfere with luteal function (Hansel \&Wagner, 1960; Hawk, Conley, Brinsfield \& Richter, 1964). Results of partially similar studies have recently been reported (Marston \& Chang, 1964; Adams \& Eckstein, 1965b).

Fifteen adult Dutch-belted does maintained under constant temperature and light conditions were assigned to three treatment groups. They were anaesthetized, the uteri exposed by a mid-line incision and $1 \mathrm{~mm}$ diameter polyethylene tubing, rounded and cuffed on the ends, was inserted through the uterine wall as follows: Group I does each received a single device $0.6 \mathrm{~cm}$ long in the lumen of one uterine horn only; Group II does received a similar device in each uterine horn; Group III does initially were treated the same as Group I, but subsequently the devices were removed and each uterine horn received a longer cuffed tube $(5.3 \mathrm{~cm})$ plus a triangular piece about $1.5 \mathrm{~cm}$ long and $1 \mathrm{~cm}$ wide. These were inserted after preliminary observations showed that small devices lying free in the lumen had no detectable effect on corpora lutea maintenance or implantation. About 1 week after the insertion of the devices the does were injected intravenously with $2.5 \mathrm{mg}$ of luteinizing hormone (Armour PLH) and inseminated with more than one million motile spermatozoa collected from the same male. Laparotomies were performed 11 to 13 days later to count the corpora lutea and inspect the uteri for implantation sites. The 
incision was closed and the does allowed to kindle. They were killed and examined 3 to 5 days afterwards.

Results are summarized in Tables 1 and 2. At the time of laparotomy the ovaries appeared to be normal, except for rather large corpora lutea in the animals which subsequently produced no young or no living young. The devices were all in the uteri excepting for Group III, where three of the long and two

TABLE 1

EFFECT OF SMALL DEVICES (GROUP I) INSERTED UNILATERALLY ON IMPLANTATION AND YOUNG BORN

\begin{tabular}{c|c|c|c|c|c|c|c|c}
\hline \multirow{2}{*}{ Doe } & \multicolumn{3}{|c|}{ No. of corpora lutea } & \multicolumn{3}{c|}{ Implants, 11 to 13 days } & \multicolumn{2}{c}{ No. of young born } \\
\cline { 2 - 9 } & $\begin{array}{c}\text { Control } \\
\text { side }\end{array}$ & $\begin{array}{c}\text { Experimental } \\
\text { side }\end{array}$ & Total & $\begin{array}{c}\text { Control } \\
\text { side }\end{array}$ & $\begin{array}{c}\text { Experimental } \\
\text { side }\end{array}$ & Total & Total & Alive \\
\hline 1 & 5 & 3 & 8 & 2 & 1 & 3 & 3 & 3 \\
2 & 4 & 4 & 8 & 4 & 4 & 8 & 0 & 0 \\
3 & 3 & 3 & 6 & 0 & 0 & 0 & 0 & 0 \\
4 & 3 & 5 & 8 & 3 & 5 & 8 & 7 & 6 \\
5 & 4 & 0 & 4 & 4 & 0 & 4 & 4 & 4 \\
Total & 19 & 15 & 34 & 13 & 10 & 23 & 14 & 13 \\
\hline
\end{tabular}

TABLE 2

EFFECT OF SMALL DEVICES (GROUP II) AND LARGE DEVICES (GROUP III) INSERTED BILATERALLY ON IMPLANTATION AND YOUNG BORN

\begin{tabular}{|c|c|c|c|c|c|c|c|c|}
\hline \multirow{2}{*}{ Group } & \multicolumn{3}{|c|}{ No. of corpora lutea } & \multicolumn{3}{|c|}{ Implants, 11 to 13 days } & \multicolumn{2}{|c|}{ No. of young born } \\
\hline & $\begin{array}{l}\text { Left } \\
\text { side }\end{array}$ & $\begin{array}{l}\text { Right } \\
\text { side }\end{array}$ & Total & $\begin{array}{l}\text { Left } \\
\text { side }\end{array}$ & $\begin{array}{c}\text { Right } \\
\text { side }\end{array}$ & Total & Total & Alive \\
\hline II & $\begin{array}{l}2 \\
4 \\
4 \\
5 \\
1\end{array}$ & $\begin{array}{l}3 \\
2 \\
1 \\
7 \\
2\end{array}$ & $\begin{array}{r}5 \\
6 \\
5 \\
12 \\
3\end{array}$ & $\begin{array}{l}3 \\
2 \\
4 \\
2 \\
1\end{array}$ & $\begin{array}{l}1 \\
2 \\
1 \\
7 \\
1\end{array}$ & $\begin{array}{l}4 \\
4 \\
5 \\
9 \\
2\end{array}$ & $\begin{array}{l}4 \\
2 \\
1 \\
7 \\
0\end{array}$ & $\begin{array}{l}1 \\
2 \\
1 \\
7 \\
0\end{array}$ \\
\hline Total & 16 & 15 & 31 & 12 & 12 & 24 & 14 & 11 \\
\hline III* & $\begin{array}{l}3 \\
4 \\
5 \\
5\end{array}$ & $\begin{array}{l}4 \\
8 \\
5 \\
3\end{array}$ & $\begin{array}{r}7 \\
12 \\
10 \\
8\end{array}$ & $\begin{array}{l}3 \\
2 \\
0 \\
1\end{array}$ & $\begin{array}{l}3 \\
5 \\
2 \\
2\end{array}$ & $\begin{array}{l}6 \\
7 \\
2 \\
3\end{array}$ & $\begin{array}{l}5 \\
1 \\
2 \\
2\end{array}$ & $\begin{array}{l}3 \\
0 \\
0 \\
0\end{array}$ \\
\hline Total & 17 & 20 & 37 & 6 & 12 & 18 & 10 & 3 \\
\hline
\end{tabular}

* One animal died during the experiment leaving four animals in this group.

of the triangular devices were missing. Two implants were developing in areas occupied by the long devices. The short devices were in various uterine locations, but a majority were near the cervix. Several embryos were developing normally in areas adjacent to the short devices. Corpora lutea represented by implantations were 68, 77 and $49 \%$ for Groups I, II and III respectively $(P<0 \cdot 05)$. In Group I the control side was not different from the experimental side $(P<0 \cdot 10)$.

Gestation length was 31 days for the normal-sized litters, and lasted 1 to 2 days longer for the small litters. This is typical for the colony of rabbits. At parturition, corpora lutea represented by live young were 38,36 and $8 \%$ for 
Groups I, II and III, respectively $(P<0 \cdot 01)$. The incidence of stillbirths was high in Group III. The three live young in this group were born from a doe which had three implantations on each side at the time of laparotomy. One side had lost the devices before laparotomy. In two does, at autopsy, the $5.3 \mathrm{~cm}$ devices had perforated the uterus and were in the peritoneal cavity. This presumably occurred at parturition, but the uteri had involuted and appeared to be normal at the time the does were killed. New follicle growth was observed on the ovaries.

These experiments confirm previous reports in the rabbit (Marston \& Chang, 1964; Adams \& Eckstein, 1965a, b) that it is more difficult to interfere with pregnancy initiation in the rabbit by inserting intra-uterine devices than it is in several other species. Implantations occurred in the presence of large intrauterine devices, including triangular ones which distended the uterus slightly. Distention can evoke increased activity in the sensitive uterus (Reynolds, 1949), but the conditions in the present experiment did not prevent implantation. Also, live young were produced in the presence of polyethylene devices not sutured to the uterine wall. Nevertheless, marked embryo mortality occurred. This was not caused by involution of the corpus luteum as was induced in cattle by oxytocin and uterine devices (Hansel \& Wagner, 1960; Hawk, Conley, Brinsfield \& Richter, 1964). However, progesterone secretion was not measured, and the fact that progesterone requirements for pregnancy (Zarrow \& Neher, 1955) might not have been met due to a decreased secretion rate or an increased local requirement for progesterone in the presence of foreign bodies cannot be excluded.

This work was partially supported by the Population Council. The authors are grateful to Dr J. J. Kennelly and Mr Ralph Maurer for assistance with the experiment.

\section{REFERENCES}

Adams, C. E. \& Eckstein, P. (1965a) Effect of intra-uterine silk threads on location and survival of conceptuses in the rabbit. 7 . Reprod. Fert. $9,351$.

ADAMs, C. E. \& Eckstein, P. (1965b) Effect of intrauterine foreign bodies on pregnancy in the rabbit. Fert. Steril. 16, 508.

Doyle, L. L. \& MARgolis, A. J. (1963) Intrauterine foreign body: Effect on pregnancy in the rat. Science, N.Y. 139, 833.

Doyle, L. L. \& Margolis, A. J. (1964) Intra-uterine foreign body studies in rodents. Proc. 2nd int. Conf. Intra-uterine Contraception, New York, p. 185.

Eckstein, P. \& Adams, C. E. (1964) Effect of intra-uterine devices on gestation in rabbits. Proc. 2nd int. Conf. Intra-uterine Contraception, New York, p. 240.

HANSEL, W. \& WAGNER, W. C. (1960) Luteal inhibition in the bovine as a result of oxytocin injection, uterine dilation, and intra-uterine infusions of seminal and preputial fluids. F. Dairy Sci. 43, 796.

HaWk, H. W., Conley, H. H., Brinsfield, T. H. \& Richter, H. F. (1964) Contraceptive effect of plastic devices in cattle uteri. Proc. 2nd int. Conf. Intra-uterine Contraception, New York, p. 189.

KAR, A. B. \& KAMBOJ, V. P. (1965) Effect of I. U. C. D. on histological and histochemical changes in rabbit uterus. Indian F. exp. Biol. 3, 141.

Marston, J. H. \& Ghang, M. G. (1964) Action of intra-uterine foreign bodies in the rat and rabbit. Proc. 2nd int. Conf. Intra-uterine Contraception, New York, p. 242.

Reynolos, S. R. M. (1949) Physiology of the uterus, 2nd edn. Hoeber, New York.

Zarrow, M. X. \& Neher, G. M. (1955) Concentration of progestin in the serum of the rabbit during pregnancy, the puerperium and following castration. Endocrinology, 56, 1.

Zipper, J., Garcia, M. L. \& PAstene, L. L. (1964) Action of intra-uterine foreign bodies: experiments in the rat and rabbit. Proc. 2nd int. Conf. Intra-uterine Contraception, New York, p. 198. 